\title{
anemon
}

Muş Alparslan Üniversitesi Sosyal Bilimler Dergisi

Journal of Social Sciences of Muş Alparslan University

Yıl/Year: 2017 • Cilt/Volume: 5 • Sayı/Number: 2

ISSN: 2147-7655 • e-ISSN: 2149-4622

ÖZGÜN ARAŞTIRMA ○ ORIGINAL ARTICLE

\section{Hive Hanı Muhammed Rahim Bahadur'un (1806-1825) 1809 Tarihli Bir Tarhanlık Yarlığının Üslubu ve Metindilbilimsel Yap1si $^{\mathrm{a}}$}

\author{
Hayrullah KAHYA ${ }^{1, b}$ \\ ${ }^{1}$ Yrd. Doç. Dr., Yıldız Teknik Üniversitesi, Eğitim Fakültesi, Türkçe Eğitimi Bölümü-İ́stanbul/Türkiye \\ Başvuru tarihi: 08 Ocak 2017 Düzeltme tarihi: 09 Mart 2017 Kabul tarihi: 22 Mart 2017
}

Öz

Bu çalışmada Hive hanlığının (1511-1920) son hanlarından Muhammed Rahim Bahadur Han (1806-1825)'ın 1809 tarihli bir yarlığının üslubu ve metindilbilimsel yapısı üzerinde durulmuștur. Söz konusu yarlık 19. yüzyıl Çağatay Türkçesi ile yazılmış bir tarhanlık yarlığıdır. Çalıșmada yarlığın önce üslup özellikleri incelenmiştir. İncelemede yarlığın üslup bakımından intitulatio (elkap), arrenga (giriş/dua/niyaz/invocatio), promulgatio (bilgilendirme/duyuru), dispositio (talep), narratio (nakil/anlatım), sanctio (tasdik), corroboratio (teyit), datatio (tarih) bölümlerine yer verildiği; locus (yer) bölümünün ise eksik olduğu görülmektedir. Daha sonra yarlığın bağdaşıklık görünümü üzerinde durulmuştur. Bağdaşıklık görünümü yarlığın yinelenmeye dayalı yapısı, art gönderimsel yapısı, bağlantı ögeleri, örtüklük yapısı, eksiltili yapısı, izleksel (tematik) yapıs1, dilbilgisel eylem zamanları ve yarlığı bölümlere ayıran belirticiler gibi çeşitli açılardan incelenmiştir. Yarlığın tutarlılık görünümü ise özelleştirme bağlantısı, sebep-sonuç bağlantısı, amaç bağlantısı, zaman bağlantısı, karşılaştırma bağlantısı gibi açılardan ele alınmıştır. Çalışmada yarlığın çeviri yazısı da yapılmıştır. Çeviri yazı verilirken tek sayfadan oluşan yarlığın her satırı yay ayraç içinde numaralandırılmıştır. Yarlığın tıpkıbasımı çalışmanın sonuna eklenmiştir.

\section{Anahtar Kelimeler}

Muhammed Rahim Bahadur Han, Hive Hanlığı, Tarhanlık Yarlığı, Üslup, Metindilbilimsel Bağdaşıklık

\footnotetext{
a Bu çalışma, 20-23 Nisan 2017 tarihlerinde İstanbul'da düzenlenen "2nd International Scientific Researches Congress on Humanities and Social Sciences (IBAD 2017)" Kongresi'nde sunulan bildirinin genişletilmiş halidir.

b Sorumlu Yazar/Correspoding Author: Yıldız Teknik Üniversitesi, Davutpaşa Kampüsü, Eğitim Fakültesi, 34220, Esenler/İstanbul/Türkiye.

e-posta: hayrullahkahya@hotmail.com 


\title{
Diplomatic Style and Textlinguistic Structure of A Yarliq of Tarkhanliq (Dated 1809) Belonging to Khan of Khiva Muhammad Rahim Bahadur (1806-1825)
}

\begin{abstract}
A manuscript called yarliq has been examined in this study. This yarliq belongs to Muhammad Rahim Khan (1806-1825) who is a khan from of Khiva Khanate (1511-1920) and ordered by him in 1809. This yarliq is a royal decree related to tarkhanliq and written in Chaghatay Turkish with Arabic alphabet on 19th century. The yarliq has been analyzed in terms of diplomatic style structure and textlinguistic structure. When its stylistic structure was analyzed it was realized that the yarliq has all sections (intitulatio, arrenga/invocatio, promulgatio, dispositio, narratio, sanctio, corroboratio, datatio) of a yarliq except locus. After this analysis cohesiveness of the manuscript was discussed in terms of its repetitional structure, anaphorical reference structure, connectoral structure, implicational structure, elliptical structure, thematic structure, grammatical tenses structure, marqueural structure, and cohesion of the manuscript in terms of its privatising link, cause and effect link, purpose link, time link, comparing link. Also its transcription was done designating parenthetically its each line. Besides, facsimile of the yarliq has been added to this study.
\end{abstract}

\section{Keywords}

Muhammad Rahim Bahadur Khan, Yarliq of Tarkanliq, Diplomatic Style, Cohesiveness

\section{GİRİ̧̧}

Harezm bölgesinde kurulduğu için Harezm Hanlı̆̆ olarak da bilinen Hive Hanlı̆̆ ${ }^{1}$ (1512-1920) 16. yüzyılda Orta Asya'daki Türk birliğinin bozulmasından sonra kurulan üç hanlıktan (Buhara, Hive, Hokand Hanlıkları) biridir. 1860'lı yıllarda Türkmenlerin isyanı gibi bazı olumsuz gelişmeler Hanlığın gücünü azaltmıştır. Bu durumu firsat bilen Ruslar da Hanlığı 1873'te işgal etmişlerdir. Bir süre Rus hâkimiyeti altında varlığını sürdüren Hive Hanlığı, 1920'de resmen ortadan kaldırılmış; yerine Harezm Halk Cumhuriyeti kurulmuştur (Alpargu 2002: 571). 1924'te de bu devlete tamamen son verilip toprakları Harizm, Özbekistan, Türkmenistan ve Kara Kalpakistan arasında paylaştırılmıştır (Saray 1998: 170).

Orta Asya, özellikle Hive Hanlı̆̆ı üzerine önemli çalışmaları bulunan bilim adamlarından Yuri Bregel (1925-2016), Orta Asya Türk tarihinde önemli bir yere sahip olan Hive Hanlı̆̆ma ait 17.-19. yüzyıllara tarihlenmiş otuz adet tarihî belgeyi 2007 yılında yayımlamıştır². Bregel söz konusu çalışmasında ele aldığı ve genellikle Hanlığın diplomasisine ilişkin bu belgeleri Arap harfleri ile yeniden dizmiş, belgelerin kısa bir 
tanıtımını yapmış ve içeriğini özetlemiştir. Çalışmasının sonunda belgelerin tıpkıbasımına da yer vermiştir.

Bu çalışmada Hive Hanlı̆̆ı tarihinde önemli bir yere sahip olan Muhammed Rahim Bahadur $\operatorname{Han}^{3}$ (1806-1825)' 'n Bregel'in hazırlamış olduğu söz konusu eserde yer alan Cemaziyelâhir 1224/Temmuz-Ağustos $1809^{4}$ tarihli bir yarlığının ${ }^{5}$ üslub özellikleri ve metindilbilimsel yapısı ele alınacaktır. Çalışmaya konu olan belge, bir tarhanlık ${ }^{6}$ yarlığ ${ }_{111 r^{7}}$. Bregel'in bildirdiğine göre, elimizdeki yarlık Hive Tarih Müzesi'nde 2089 kayıt numarası ile koruma altındadır. Tıpkıbasımdan anlaşılmamakla birlikte Bregel, yarlıktaki mühürlerden birinde "Raḥīm Kulı H(w)ārezm-şāh" yazısının okunduğunu belirtmektedir (Bregel 2007: 19). Yarlığın sağ kenarında okunaksız iki mühür daha bulunmaktadır. Çalışmaya konu olan yarlıkta, Muhammed Rahim Bahadur Han tarafından halife Hz. Ali'nin soyundan geldiği söylenen Savmaî Ata ${ }^{8}$ adlı bir evliyanın oğullarından Yusuf Hoca, Ata Can Hoca, Baba Can Hoca, Geday Hoca, Sikender Hoca, Kalender Hoca, Nuruddin Hoca, Avaz Hoca ve Güman Hoca'ya tarhanlık verildiği anlaşılmaktadır. Yarlıkta adı geçen tarhanlara tüm vergilerden muafiyet hakkı tanınmış ve onlara devlet memurları tarafindan herhangi bir eziyet edilmemesi veya güçlük çıkarılmaması da buyurulmuştur. Bu çalışmada yarlığın önce üslup özellikleri, daha sonra metindilbilimsel yapısı incelenmektedir.

\section{YARLIĞIN ÜSLUP ÖZELLIKKLERİ}

Yarlıklar konularına, amaçlarına ve dönemlerine göre az çok farklılık göstermekle birlikte yüzyıllar süren devlet geleneği içinde kalıplaşmış şekilleriyle yazılagelmişlerdir (Özyetgin 1996: 77). Bu yüzden yarlıkları üslup bakımından incelemek demek, bir bakıma bu kalıplaşmış yapı üzerinde durmak demektir.

Yarlıklar genellikle yarlığı yazdıran hükümdarın adından sonra Türkçe kalıp bir ifade olarak sözüm şeklinde başlar (Özyetgin 1996: 81). Elimizdeki yarlık ise "Allah" anlamındaki hū'dan sonra Ebu'l-mużaffer ve'l-manșūr Muhammed Raḥīm Bahādur hān sözümiz şeklinde başlamaktadır. Hanın adından önceki unvanların olduğu bölüm intitulatio (elkap) bölümü olarak değerlendirebilir. Yarlığın arrenga (giriş/dua/niyaz/invocatio) bölümünde yüce Allah'a hamd; kurbet (yakınlık) makamını kazanmış Hz. Peygambere tahiyyat ve onun âl ve ashabına selam ifade edilmiştir. Arrenga bölümünden sonra gelen promulgatio (bilgilendirme/duyuru) bölümünde hanın kardeş, oğul gibi akrabaları (karıntaşlar, iniler ve oğullar), ardından ḳaraçu biyler, dīvānlar, hāâbler, kāộ̄lar, aka ve arbāblar, 'ummāllar ve son olarak Harezm'deki özellikle Hive'deki halka ${ }^{9}$ (sekene-i H(W)ārazm hususan Hīvak) hitap etmektedir. Dispositio (talep)'yu takip eden narratio (nakil/anlatım) bölümünde asıl buyruğun ifade edildiği görülmektedir. Burada han, Savmaî Ata'nın oğullarının vermiş olduğu dilekçeye ${ }^{10}$ istinaden onların soyunun Hz. Ali’ye -dolayısıyla ehl-i beyte- dayandığını ögrendikten sonra ruhuna hürmet niyetiyle onun dokuz oğluna ( Yusuf Hoca, Ata Can Hoca, Baba Can Hoca, Geday Hoca, Sikender Hoca, Kalender Hoca, Nuruddin Mahdum, Avaz Hoca ve Güman Hoca) tarhanlık ve buna bağlı olarak bütün vergilerden muafiyet imtiyazı verdiğini ifade etmektedir. Dispositio'nun devamında bu yarlığı görenlerin yarlıkta adı geçenlerin tarhan olduklarını ve vergilerden muaf tutuluklarını bilmeleri gerektiği ifade edilmiştir. Bu bağlamda tarhanlardan 'ameldār, ehl-i kalem, élçi, yolçı, bācbān, keştībān, 
korug̉bān, dervāzebān, terāzūbān, biy, karavul ve kötevül gibi devlet memurlarının herhangi bir vergi talep etmemeleri ve onlara herhangi bir zahmet veya zarar verilmemesi emredilmektedir. Burada devlet memurlarının söz konusu şahıslardan her yıl tasdikli bir yarlık (tāze nişānn) talep etmemeleri de buyurulmaktadır. Böylece adı geçen şahıslar beş vakit namazdan sonra temiz bir gönül ve rahatlık içinde devletin bekası için dua edeceklerdir. $\mathrm{Bu}$ bölüm sanctio (tasdik) ve corroboratio (teyit) bölümlerini oluşturmaktadır. Yarlı̆̆ın son bölümü datatio (tarih)'dur. Buna göre yarlık, Hicrî 1224 senesinin Cumada's-sani ayında yazılmıştır. Bu tarih Miladî 1809 yılının Temmuz veya Ağustos aylarına denk gelmektedir. Elimizdeki yarlıkta locus (yer) bölümü yoktur.

Yarlıklar genel olarak mukaddime kontekstve son protokololmak üzere üç ana bölümde incelenebilir. Elimizdeki yarlığın intitulatio, arrenga ve promulgatio bölümleri mukaddime; dispositio, narratio, sanctio ve corroboratio bölümleri kontekst; datatio bölümü ise son protokolbölümleri içinde değerlendirilebilir.

Elimizdeki yarlığın övgü ifadeleri dışında sade yazılmış bir metin olduğu söylenebilir. Ayrıca metnin içeriğine uygun olarak metinde vergi ve devlet yönetimi ile ilgili birçok terimin geçtiği görülmektedir.

\section{YARLIĞIN METİNDİLBILIMSEL YAPISI}

Batı'da 20. yüzyılın ikinci yarısında ortaya çıkan metindilbilim (textlinguistics) çalışmalarının Türkiye'de yaygınlaşması bin dokuz doksanlı yıllara rastlar. Metindilbilim, bir metni oluşturan unsurların belli yöntemlerle dilbilimsel açıdan çözümlemesini ele alan bir bilim dalı olarak tanımlanabilir. Teorik anlamda metindilbilim konusunda ilk çalışan bilim adamlarının başında M. A. K. Halliday ve Ruqiya Hasan (1976), Gillian Brown ve Goerge Yule (1986) gibi araştırmacılar gelir. Bu araştırmacılar, cümlelerin bir metin oluşturabilmesi için cümleler arasında bağdaşıklık, uyum ve tutarlılık olması gerektiğini ileri sürmüşlerdir. Metnin bu özellikleri sayesinde okuyucu veya dinleyici, metni daha iyi algılayacak ve metnin geneli ile ilgili varsayımlarda bulunabilecektir (Demirci 2014: 217-218).

Türkçede "dokuma, dokumacılık" anlamlarındaki tekstilkelimesi ile aynı köke sahip olan metin (Fr. texte, Ing. text), -kumaşın ipliklerden dokunarak bir bütün oluşturması gibikendisini oluşturan ögelerin birbirine aşama aşama eklenmesi sürecinin sonunda ortaya çıkar (Akbayır 2013: 189). Bir metnin bir cümleler yığını olmaktan çıkıp bir metin haline gelebilmesi için içerdiği bazı bilgilerin çeşitli şekillerde tekrarlanması, bir taraftan da sözün bir amaca, bir sona doğru gelişerek ilerlemesi gerekmektedir. Bu, metne yeni ögelerin ve bilgilerin katılması yoluyla yapılır. Bir metin aynı zamanda mantıksal ve anlamsal bütünlüğe de sahip olmalıdır. Metinde birbiriyle çelişen duygu ve düşüncelere yer verilmemesi, metindeki göndergelerin dış dünyanın gerçekleriyle örtüşmesi ve mantıksal bir ilişki içinde bulunması gibi özellikler cümle yığınlarının bir metin oluşturmasını sağlayan etmenlerdendir ${ }^{11}$ (Onursal 2003: 125).

Metindilbilimsel olarak bir metin, bağdaşıklık ve tutarlılık gibi açılardan incelenebilir. $\mathrm{Bu}$ çalışmada söz konusu yarlığın bağdaşıklık ve tutarlılık görünümü ${ }^{12}$ üzerinde durulacaktır.

Metindilbilim ile ilgili çalı̧̧malarda farklı inceleme yöntemlerinin uygulandığ görülmektedir (bkz. Aydın ve Torusdağ (2014)). Bu çalışmada, metnin bağdaşıklık 
görünümleri Günay'a (2003) ve tutarlılık görünümleri ise Subaşı Uzun'a (1995) göre incelenmektedir.

\subsection{Yarlığın Bağdaşıklık Görünümü}

Bağdaşıklık (cohesion), metni oluşturucu ögelerin yinelenmesi, art gönderim, ön gönderim, eksiltili yapılar, örtük anlatımlar, izlekler ve örgeler, dilbilgisel eylem zamanları gibi çeşitli açılardan incelemeye dayanır (Günay 2003: 52-87). Özne-yüklem uygunluğu, öge eksikliği, gereksiz öge kullanımı, ögelerin yanlış dizimi, gönderim ögelerinin yanlış dizimi, yinelemelerin sıklığı gibi ögeler de bağdaşıklık ögeleri olarak değerlendirilebilir (Karaağaç 2015: 362-363). Bağdaşıklık metnin dilbilgisel özelliklerini, başka deyişle kelime ve kelime gruplarının birbirleriyle ilişkilerini ortaya koyan dilbilgisel seviyeyi temsil eder. Bu, bir bakıma metnin yüzey yapısını ele almak demektir (Demirci 2014: 219).

$\mathrm{Bu}$ bölümde söz konusu yarlığın bağdaşıklık görünümü yarlığın yinelenmeye dayalı yapısı, art gönderimsel yapısı, bağlantı ögeleri, örtüklük yapısı, eksiltili yapısı, izleksel (tematik) yapısı, dilbilgisel eylem zamanları ve yarlığı bölümlere ayıran belirticiler gibi çeşitli açılardan incelenmiştir.

\subsubsection{Yarlı̆̆ın Yinelenmeye Dayalı Yapısı}

Her metinde her türlü dilsel yapı değişik şekillerde metin boyunca yinelenebilir. Metindeki kişilerin, uzamın, eşyanın, durumun, nesnenin yinelendiği görülür. Böylece cümleler arasında bağlantı sağlanır (Günay 2003: 61). Bu da metnin bağdaşıklık unsurlarından birini oluşturur:

İmdi bu fermān-1 hümāyun-1 'àlī mażmūnig̀a muțtali' bolg̉aç bu mežkūr bolgan camā'atnı (...) Tā kim bu mezkūr bolgan cemā'at tinç köngül ve āsūde-ḩātır bolup ba'da ez-adā-yı șalavāt-1 hamse bizning du' $\bar{a}-y 1$ devlet-i ebed-muddatımızǵa meşğ $\bar{u} l$ bolgaylar (...)

Yukarıdaki iki cümlede geçen bu mezkūr bolgan cemā`at sözcük öbeğiyle kişilerin yinelendiği görülmektedir.

(...) muşārun ileyhimlerining aḥvālığa şāmil ḳılıp körüp bilip tarhān ve marfü' u'l-kalem kılduk. İmdi bu fermān-1 hümāyun-1 'ālī mażmūniga muttali ' bolgaç bu mezkūr bolgan camā'atnı tarhān ve marfü' 'u'l-kalem bilip (...) cümlesinde ise tarhān ve marfü' u'l-kalem bağlama öbeği yapısındaki gönderge yinelenmiştir.

\subsubsection{Yarlığın Art Gönderimsel Yapısı}

Metindilbilimsel açıdan her metinde art gönderim veya ön gönderimsel birimler bulunabilir. İncelediğimiz yarlıkta art gönderimsel ilişkiler bulunmaktadır.

Art gönderimsel ilişkide metin içinde önce söylenen herhangi bir kişi, izlek, durum, nesne ya da kavram daha sonra aynı yahut farklı şekillerde tekrar eder. Metnin bağlamsal durumu ile ilgili olan bu tür yapılar metnin bağdaşıklık niteliklerinden birini oluşturur. Art gönderimler, adıl kullanımı ile art gönderim, sözcüksel art gönderim, gösterilenin 
yinelenmesi ile art gönderim, çağrışımsal art gönderim, belirteçle yapılan art gönderim, ortak göndergesi olan art gönderim, çok bağımlı art gönderim ve önvarsayımsal art gönderim gibi kendi içinde çeşitli şekillerde karşımıza çıkabilirler (Günay 2003: 61-66).

$\mathrm{Bu}$ çalışmada incelenen yarlıkta sözcüksel art gönderim ile göndergenin yinelenmesi yoluyla oluşturulmuş art gönderim örnekleri bulunmaktadır: (...) bu uçurda kuțbu'levliyā ve senedü'l-etkiyā Șavma' 1 A ta (عليه الرحد)ning neseb-i mübārekleri hażret-i 'Al̄̄ (كرم الله وجهه

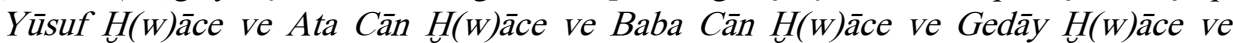
Sikender $H(w) \bar{a} c e$ ve Kalender $H(w) a \bar{c} e$ ve Nūru'd-dīn Mahdūm ve 'Avaż $H(w) a \bar{c}$ ce ve

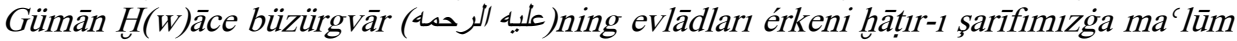
bolgan üçün (...)

Yukarıdaki cümlede önce adı söylenen Savma`'̄ Ata'dan daha sonra büzürgvār-1 mezkūrnıng ve büzürgvā̄ şeklinde söz edilerek art gönderim yapılmıştır.

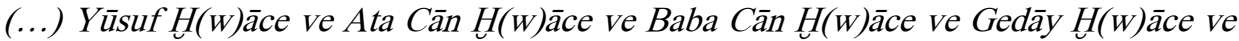
Sikender $H(w) \bar{a} c e$ ve Kalender H(w)āce ve Nüru'd-dīn Mahdūm ve 'Avaż $H(w) \overline{a c e}$ ve

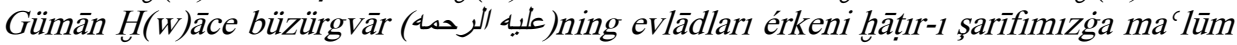
bolg̀an ücün zerre-i āftāb-1 'ināyetimizni muşārun ileyhimlerining aḥvāliğa şāmil ḳılıp (...) cümlesinde öncelikle Savmai Ata'nın oğullarının adı zikredilmiş, akabinde aynı kişilere muşârun ileyhim denilerek art gönderim yapılmıştır. Aynı kişilere (...) Imdi bu fermān-1 hümāyun-1 'ālī mażmūnıġa muțtali' bolgaç bu mezkūr bolgan camā'atnı (...)Tāa kim bu mezkūr bolgan cemā' at tinç köngül ve āsūde-hātırı bolup ba' da ez-adā-yı șalavāt1 hamse bizning $d u^{\prime} \bar{a}-y 1$ devlet-i ebed-muddatımızǵa meşgüul bolgaylar (...) cümlelerindeki bu mezkūr bolgan camâa $\bar{a}^{`}$ göndergesiyle yeni bir art gönderim daha yapılmıştır.

\subsubsection{Yarlı̆̆ın Bă̆lantı Ögeleri}

Metnin bağdaşıklık durumu ve metinde yukarıda sözü edilen "bir taraftan ilerlemenin" metnin yüzeyinde oluşturulması bağlantı ögesi/bağıntılayan dilbilgisel ögelerle sağlanır (Onursal 2003: 127).

Yarlıkta en çok kim, ve, $u$, birle bağlantı ögeleri kullanılmıștır. Bu kullanıma şu cümleler

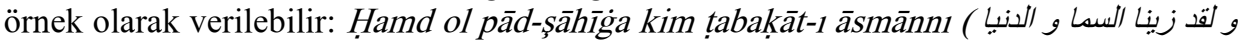

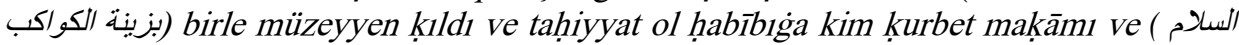
(عليك ايها النبى و رحمة الله و بركاته birini necm-i hādī ḳıldı.(...) Bes makșūd bu mukaddemedin bu kim hūrsşīd-i kadr ve āsmān-1 bedr karıntaşlar birle hukukūmet-penāh settāre-sipāh berhūurdār ini ve og̀ullarga (...)

Burada kim, ve, $u$, birle bağlantı ögeleri kendinden önceki göstergenin ayrıntısını ifade ederek veya iki düşünceyi ya da göstergeyi doğrudan birbirine bağlama görevini üstlenerek metnin bağdaşıklığına katkı sağlamıştır.

Yarlıkta rastladımız bir diğer bağlantı ögesi bes'tir: Bes makṣūd bu mukaddemedin bu kim hūrş̧īd-i kadr ve āsmān-1 bedr karıntaşlar birle ḥukūmet-penāh settāre-sipāh berhūūrdār ini ve ogullarga (...) 
Yukarıdaki cümlede geçen bes bağıntılayanı, yüzey yapıda metindeki zamansal değişimi ve gelişimi göstermekle birlikte derin yapıda metne konu olan düşüncenin başlangıcı ile metnin giriş bölümünün ilişkisini sağlamaktadır. Bu yönüyle bu bağıntı ögesinin burada amaç bă̆ıntısı görevinde olduğu söylenebilir.

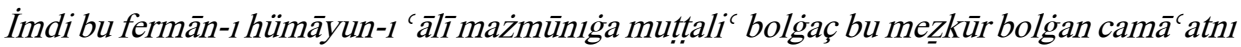
tarhān ve marfü'u'l-kalem bilip küllü tekālīf-i dīvān̄̄ ve me 'unāt-1 sulțānīdin sivā u müsteșnā bilip küllü 'ameldārlar kademlerin ve ehl-i kalem kalemlerin tarta tutsunlar (...) cümlesindeki imdi bağıntı ögesi de metnin üreticisi tarafından alıcısı olan okuyucuya/dinleyiciye bir önceki düşüncenin gereğinin yapılmasını ifade etmek amacını taşımaktadır. Bu bağıntı ögesi, öncesi ve sonrası arasında uslamlama ilişkisi kurmaktadır. Söz konusu bağıntılayanda pekiştirme ve vurgulama işlevi de baskındır.

Yarlıkta geçen bir başka bağıntı ögesi de Tā kim'dir. Bu bağıntı ögesi, metinde kendinden önce ve sonra gelen düşünceler arasındaki zamansal süreci göstermektedir. Bununla birlikte söz konusu bağıntılayanda sonuç işlevi de belirgindir: (...) her yılda tāze nişsān tilemesünler. Tā kim bu mezkūr bolg̀an cemā'at tinç köngül ve āsūde-ȟattır bolup ba'da ez-adā-y1 șalavāt-1 hamse bizning $d u^{`} \bar{a}-y 1$ devlet-i ebed-muddatımızǵa meşğūl bolgaylar tép tārīh-i hicrī ming taḳı iki yüz yigirme törtde cumāda's s-ṣānī ayıda mührlik nişān bitildi. Sene 1224.

Yukarıdaki cümlede geçen bir başka bağıntılayan da tép’tir. Bu bağıntı ögesi burada amaç bağıntısı işlevindedir.

\subsubsection{Yarliğıı Örtük Yapısl}

Bir metinde herşey genellikle tamamıyla ifade edilmez. Dilbilimsel olarak eksik anlatım ya da alıcının çıkarsama yapma veya sezme yoluyla tamamlaması gereken değişik biçimler olur. Örtükleşme denen bu durum, dolaylı ya da doğrudan ulaşılabilecek bilgiler için kullanılır. Metnin örtük yapısı sezdirimler, çıkarsamalar, önvarsayıltılar vb. yoluyla ortaya konur. Çıkarsamalar bir çeşit akıl yürütme işidir. Metin içinde açıkta belirtilen göndergelerden yahut metnin muhtemel alıcılarının bildiği varsayılan kültürel veya ansiklopedik bilgilerden yola çıkarak metinde açıkta söylenmemiş bilgileri ortaya koymak, bir çeşit çıkarsama yapmaktadır. Buna önvarsayımsal çıkarımlar da denebilir. Sezdirimler, metnin yapısı içinde anlamsal ve mantıksal akıl yürütme ile kazanılacak ek bilgileri elde etme olarak tanımlanabilir (Günay 2003: 70-72).

Yarlıkta kültürel bakımdan örtük anlatımlara rastlandığ 1 görülmektedir. $\mathrm{Bu}$ husus, yarlığın Türk-İslam kültürü ve medeniyetinin hâkim olduğu bir toplumda üretilmesinin bir sonucudur. Yarlıktaki örtük anlatımlara şu örnekler verilebilir:

$H \bar{u}$

Yarlık "o" anlamına gelen "Hū" ile başlamaktadır. Buradaki kelimenin "Allah, Tanrı" anlamında olduğu alıcı tarafından çıkarım yoluyla anlaşılmaktadır. Çünkü İslam kültüründe bu kelime "Allah" yerine çokça zikredilir. 
Hamd ol pād-şāhīga kim tababạāt-1 āsmānnn (و لقد زينا السما و الدنيا بزينة الكواكب) birle müzeyyen

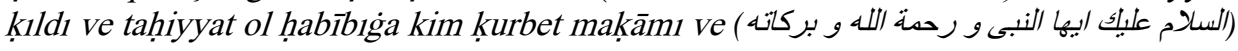
tép mu'ayyen ḳıldı ve selām anıng āl u aṣhāblarig̉a kim her birini necm-i hādī ḳıldı.

Yukarıdaki cümle dizisinde "Allah”tan pād-şāh olarak söz edilmektedir. țabakāt-1 āsmān

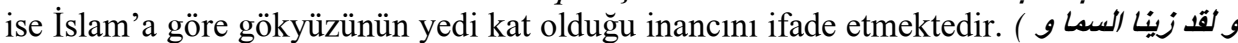
ise Müslümanların kutsal kitabı Kur'an-1 Kerim'den alınmış bir ayettir. Yarlıkta İslam peygamberi Hz. Muhammed'den ise "dost, sevilen" anlamında habīb olarak bahsedilmektedir. Çünkü yine İslam'a göre Hz. Muhammed Allah'ın habibidir. kurbet makāmı ve (السلام عليك ايها النبى و رحمة الله و بركاته ilinadelerinde ise Hz. Muhammed'in bir mucizesi olarak Mirac'a yükselmesi ile ilgili bir bilgi örtük olarak ifade edilmektedir. Yine İslam'a göre Hz. Muhammed canlı olarak gökyüzüne yükselerek olarak Allah ile görüşmüştür. "Selam sana ey nebi! Allah'ın rahmeti ve bereketi üzerine olsun." anlamındaki (السلام عليك ايها النبى و رحمة الله و بركاته cümlesi bu görüşme esnasında geçmektedir. Ayrıca Hz. Peygamber bir hadisinde âl ve ashabının her birinin bir hidayet yıldızı olduğu ifade etmiş̧tir. necm-i hād̄̄ "hidayet yıldızı" sözcük öbeği bu örtük bilgiyi ifade etmektedir.

(...) bu uçurda kuṭbu'l-evliyā ve senedü'l-etkiyā Savma'̄i Ata (عليه الرحمد)ning neseb-i mübārekleri hażret-i 'Alī (كرم الله وجهه ga yetişe turur. Büzürgvār-1 mežkūrning rūhh-1 şerifflerin șlap ve hürmet kıllp (...) ifadelerinde metin üreticisinin yaşadığ toplum olan Müslüman toplumunda evliya, etkiya gibi kişilere ve bunlar arasında özellikle soyu $\mathrm{Hz}$. Ali'ye dayananlara hürmet edilmesi gerektiği sezilmektedir. Soyun Hz. Ali'ye dayanması, kişinin Hz. Peygamberin soyundan gelmesi anlamına geldiği ise çıkarım yoluyla anlaşılmaktadır. İslam inancı, peygamberin soyundan gelenlere saygı göstermeyi gerektirmektedir. $\mathrm{Bu}$ örtük bilgi de metnin alıcısı tarafından çıkarsama yoluyla anlaşılmaktadır.

Yarlıkta kültürel örtüklük dışında başka örtük bilgilere de rastlanılmaktadır. Bu bilgilere dilsel, bağlamsal veya durumsal çıkarımlar ya da sezdirimler yoluyla ulaşılabilir:

Bes makșūd bu mukaddemedin bu kim hürrșīd-i kadr ve āsmān-1 bedr karıntaşlar birle hunkūmet-penāh settāre-sipāh berhūurdār ini ve og gullarğa, 'ālī-makām sa'ādet-fercām diyānet ve ş̧ecā'atlık șāyib-rāy karaçu biylerge, zerrīn-kalem ve müsskinn-rakam dīvānlar

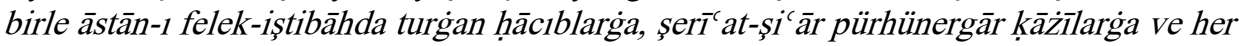

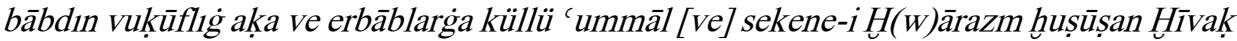
الحسن الله /حوالهم) tesadüfi değil, belli bir önem derecesine göre olduğu sezdirim yoluyla anlaşılmaktadır. Buradaki dizilişe göre kişi ve makam bakımından en önemli/yüksek/yüce olandan aşağıdaya doğru sıralanış şu şekildedir: kardaşlar ${ }^{13}$ ile küuçük erkek kardeş ve oğullar ${ }^{14}$, karaçu biyler, divanlar, hacipler, kadllar, aka ve erbablar, bütün ummal ve Harezm, özellikle Hive sakinleri.

Bu dizilişte de karındaşlarile küçük erkek kardeş(ini) ve oğullar arasındaki önem farkının azlığı bağıntı ögeleriyle sağlanmıştır. Aynı durum varlığı aka ve arbablar arasında da görülmektedir. Hive sakinlerinin Harezm sakinlerine göre daha önemli olduğu ise huușụșan "özellikle" kelimesi ile sezdirilmiştir. Bu durum, Hive'nin başkent olmasından kaynaklanmış olmalıdır. 
Yarlıkta tarhanlık verilen kişilerden hiçbir vergi alınmaması ile ilgili emirler sıralanırken devletin resmî postacı veya habercilerinin diledikleri evlere konaklayıp onların hayvanlarından diledikleri ile yola devam edebildikleri bilgisi (...) élçi ve yolçı barğuçı ve kélgüçi öylerige tüşüp kelle ve karalarıdın ulag tutmasunlar (...) ifadesinden sezilmektedir. Benzer şekilde (...) bir habbe bir dīnār țama' u tavakku' kılmasunlar (...) ifadesiyle bazı vergi tahsildarlarının açgözlü oldukları sonucuna ulaşılabilir.

\subsubsection{Yarlığın Eksiltili Yapısı}

Bir cümlede bir veya daha çok ögenin eksik bırakılması olarak nitelenebilecek eksiklik, bağlamsal bir olaydır. Özellikle konuşma dilinde çok görülür. Özne, yüklem, nesne, tümleç veya tamlayan eksikliği vb. eksiltili yapılara rastlanabilir. Ancak bir cümle içinden kelime ve kelimelerin atılması/eksik bırakılması, cümlede anlam kaybına neden olmayacak şekilde yapılır. Alıcının bu tür eksiklikleri tamamlayabilmesi onun bireysel özellikleri ile ilgili olduğu kadar metnin ifade edildiği dili ve o dilin anlatım imkânlarını bilme derecesiyle de ilintilidir (Günay 2003: 67-69). Yarlıkta geçen özne, yüklem, tümleç, fiilimsi, iyelik eki vb. eksiltili yapıların tümü parantez içinde aşağılda belirtilmiştir:

\section{Hū (Allāh turur)}

(Mén) Ebu'l-mużaffer (bolg̀an) ve'l-manșūr (bolgan) Muḥammed Raḥim Bahādur hā̄n (mén). (Bizning) sözümiz (bu durur kim) ḥamd ol pād-şāhīga (bolsun) kim (ol) țabakạat-1 āsmānnı (و القد زينا السما و الدنيا بزينة الكواكب) birle müzeyyen kildı ve tahiyyat (anıng) ol

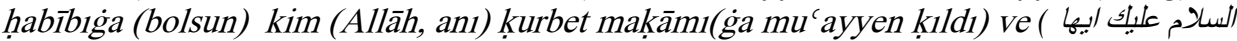
(النبى و رحمة الله و بركاته (ol Allāh anların) her birini necm-i hādī kıldı. Bes makșūd bu mukaddemedin bu (durur) kim hūrsșīd-i kadr (bolgan) ve āsmān-1 bedr (bolgan) karıntaşlar(ımız) birle hukūmetpenāh settāre-sipāh (bolgan) berhūrrdār ini(lerimiz) ve og̉ullar(ımız)ġa (ma 'lūm bolsun kim ve takı) 'āli-makāam (bolg̀an ve) sa'ādet-fercām (bolgan) diyānet ve şecā'atlık (bolg̀an) șāyib-rāy karaçu biyler(imiz)ge (ma'lūm bolsun kim ve takı), zerrīn-kalem (bolg̀an) ve müşkinn-rakam (bolg̀an) dīvānlar(ımız) birle āstān-ı felek-iştibāhda turğan

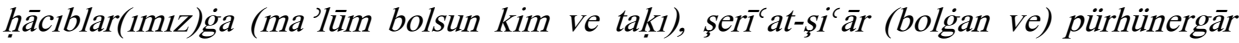
(bolġan) kāżìlar(ımız)ġa (ma'lūm bolsun kim) ve her bābdın vuküflıg (bolgan) aka(larımızǵa ma 'lūm bolsun kim) ve erbāblar(ımız)ga (ma'lūm bolsun kim ve takı) küllü 'ummāl(ımızg̀a ma'lūm bolsun kim ve takı) sekene-i H(w)ārazm(ga ma 'lūm bolsun

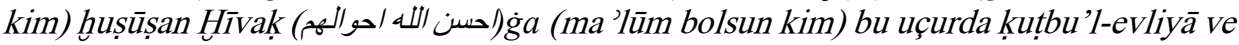
senedü'l-etkiyā (bolgan) Șavma'ī Ata (عليه (الرحمد)ning neseb-i mübārekleri hażret-i 'Alī

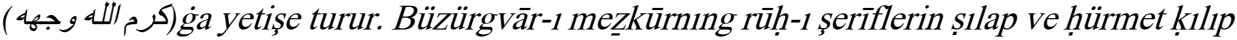

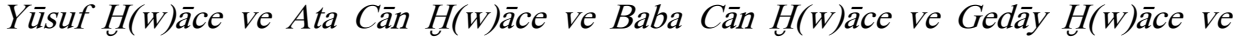
Sikender $H(w) \bar{c} c e$ ve Kalender $H(w) a \bar{c} e$ ve Nüru'd-dīn Mahdūm ve 'Avaż $H(W) \bar{a} c e$ ve Gümān H(W)āce büzürgvārr (عليه الرحمد)ning evlādları érkeni (bizning) hăạtır-1 ş̧arīfimızǵa ma'lūm bolg̀an üçün (bizning) zerre-i ăftāb-1 'ināyetimizni muşārun ileyhimlerining ahvālgǵa şāmil kıllp (anları) körüp (ve) bilip (biz) tarhān (kıllduk) ve marfü'u'l-kalem kılduk. İmdi (küllü 'ameldārlar ve ehl-i kalem) bu fermān-1 hümāyun-1 'ālī mażmūnı̀ga mutțali' bolg̀aç bu mezkū̄r bolgan camā'atnı tarhān (bilip) ve marfü' 'u'l-kalem bilip (anları) küllü tekālīf-i dīvānī(din sivā u müsteșnā bilip) ve me 'unāt-1 sulțānīdin sivā u 
müstesnā bilip küllü 'ameldārlar kademlerin (tarta tutsunlar) ve ehl-i kalem kalemlerin tarta tutsunlar ve (bu mezkūr bolgan camā'at) her yerde ékin ékseler ve (bu mežkūr bolgan camā'at) nihāl tikseler (küllü 'ameldārlar ve ehl-i kalem, anlardın) carīb (tilemesünler) u țanābāne tilemesünler ve (küllü 'ameldārlar ve ehl-i kalem, anlarnıng) yepekleridin māl almasunlar, élçi ve yolçı barğuçı ve kélgüçi (anlarıng) öylerige tüşüp (anlarnıng) kelle(leridin) ve karalarıdın ulag tutmasunlar, bācbān ve keştībān ve koruğbān ve dervāzebān ve terāzūbān, biy, karavul ve kötevül (anlardın) bir habbe (țama' u tavakku' kılmasunlar) bir dīnār țama`u tavakku' kılmasunlar, (bular anlara) hīç vechdin żarar (yétkürüp) u zaḥmet yétkürüp āzurde-hātır kılmasunlar ve (bular anlardın) her yılda tāze nişān tilemesünler. Tā kim bu mežkūr bolg̀an cemā'at tinç köngül ve āsūde-ȟătır bolup (bu mezkūur bolgan cemā'at) ba'da ez-adā-y1 șalavāt-1 hamse bizning $d u^{\prime} \bar{a}-y 1$ devlet-i ebed-muddatımızǵa meşg̀ūl bolǵaylar tép tārīh-i hicrī ming taḳ iki yüz yigirme törtde cumāda'ș-șānī ayıda (bu) mührlik nişān (küllü 'ameldārlar ve ehl-i kalem ve sā’iraġa āgāh bolsun tép bu mežkūr bolg̀an camā' at üçün bizning cānibimizdin) bitildi. Sene 1224.

\subsubsection{Yarlı̆̆ın İzleksel (Tematik) Yapısı}

Metnin teması, onun izleğidir. Örge ise izleği oluşturan her bir alt ögeye verilen addır. Başka deyişle izlek, örgelerden oluşur. Her metnin tek bir temel izleği olmakla birlikte metinde birden fazla izleğe ve onun alt ögeleri olan örgelere de rastlanabilir. Örgeler ile izlek arasında hiyerarşik bir düzen vardır. Başka deyişle bir izlek, daha geniş yapıdaki bir izleğin alt ögesi olduğunda söz konusu izlek, örge durumuna geçer. Benzer şekilde bir izleğin örgesi daha küçük bir yapıda örgeleri olabilen izleğe dönüşebilir (Günay 2003: 73-75).

Elimizdeki yarlığın temel izleği, Savmai Ata'nın oğullarına tarhanlık verilmesidir. Bu izleğin örgeleri ise şöyle siralanabilir:

- Savmai Ata'nın zamanın evliyalarından olması

- $\quad$ Savmai Ata'nın soyunun Hz. Ali'ye dayanması

- $\quad$ Savmai Ata'nın ruhuna hürmet edilmesi

- Yusuf Hace, Ata Can Hace, Baba Can Hoca, Geday Hoca, Sikender Hoca, Kalender Hoca, Nuruddin Mahdum, Avaz Hoca, Güman Hoca'nın Savmai Ata'nın oğulları olduğunun öğrenilmesi ${ }^{15}$

- Han'ın inayetinin Savmai Ata'nın oğullarına da gösterilerek onlara tarhanlık verilmesi

- Devlet memurlarının söz konusu kişilere gereken ayrıcalığı tanımaları

Yukarıdaki örgelerin en sonuncusu da temel izleğe bağlı bir alt izlek olarak düşünülebilir. Bu durumda söz konusu izleğin örgeleri ise şu şekilde sıralanabilir: 
- Fermanın devlet memurlarına ulaşınca adı geçen kişilerin tarhan olarak tanınması

- $\quad$ Söz konusu tarhanlık verilenlerin vergilerden muaf tutulması

- $\quad$ Elçi ve yolcuların söz konusu kişilerden vergi veya ulak hayvanı almamaları

- Devlet memurlarının "bir habbe bir dinar" kadar bile onlardan bir talepte bulunmamaları

- $\quad$ Söz konusu kişilere herhangi bir zarar veya sıkıntı verilmemesi

- $\quad$ Söz konusu kişilere verilen yarlığın her yıl onaylı yeni nüshasının (taze nişan) talep edilmemesi

Yukarıdaki Söz konusu tarhanlık verilenlerin vergilerden muaf tutulması örgesi de bir alt izlek olarak düşünülebilir. Bu durumda bu izleğin örgeleri şu şekilde sıralanabilir:

- Söz konusu kişilerin ektikleri ekin veya diktikleri fidanlardan tarım vergilerinin alınmamas 1

- $\quad$ Söz konusu kişilerin ipekli mallarından vergi alınmaması

Benzer şekilde Söz konusu kişilere herhangi bir zarar veya sıkıntı verilmemesi örgesi de bir alt izlek olarak düşünüldüğünden bu izleğin örgesi şu şekilde olabilir:

- Tarhanlık verilen kişilerin huzur içinde olmaları

- $\quad$ Söz konusu kişilerin beş vakit namazlarından sonra devletin bekası için dua etmeleri

\subsubsection{Yarlığın Dilbilgisel Eylem Zamanları}

Herhangi bir dildeki eylem çekimleri zamansal bir işleve sahiptir. Bu çekimler cümleler arasındaki öncelik sonralık ilişkilerini açıklar. Eylemler zaman, kip ve görünüş bakımından incelenirler. Metindeki kipsel yapılar, anlatıcının metnin alıcısına karşı takındığı tavrı ortaya koyduğu için metnin çözümlenmesi açısından çok önemlidir. Alıcı, kipsel yapılar yoluyla anlatıcının konuya ilişkin tavrını (dilek, bilgilendirme, emir, istek, niyet, beklenti vb.) öğrenme imkânı bulur (Günay 2003: 75-77).

Yarlıkta geçen dilbilgisel eylem zamanları geçmiş zaman, şimdiki zaman ve gelecek zamandır. Bir ferman olmasının doğal sonucu olarak yarlıkta emir (buyurma) kipi de sıklıkla kullanılmıştır.

Geçmiş zaman: Yarlıkta eylemin yaptığı işin geçmiş zamanda yapıldığını kesin olarak bildiren belirli geçmiş zaman kullanımına rastlanmaktadır: Hamd ol pād-şāhīg̀a kim tabakāt-1 āsmānnı (و لقد زينا السما و الدنيا بزينة الكواكب) birle müzeyyen ḳıld1 (belirli geçmiş 


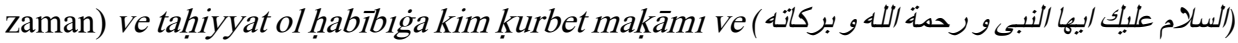
tép mu'ayyen ḳıldı (belirli geçmiş zaman) ve selām anıng āl u așhāblarığa kim her birini necm-i hādī k̂ldı (belirli geçmiş zaman) (...) büzürgvār-1 mezkūrnıng rūhh-1 şerîflerin șilap

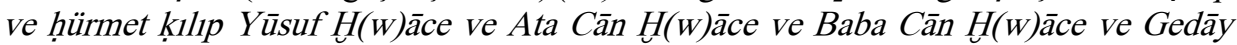

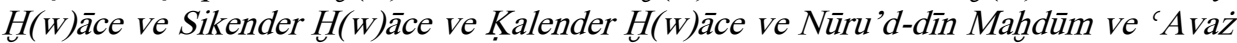

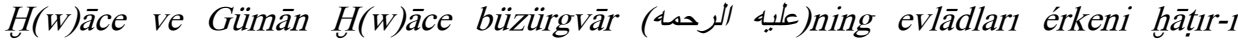
şarīfimıża ma' lūm bolgan üçün zerre-i āftāb-1 'ināyetimizni muşārun ileyhimlerining aḥvālıga şāmil ḳılıp körüp bilip tarhān ve marfü' $u$ 'l-kalem kılduk (belirli geçmiş zaman) (...) tārīhh-i hicrī ming taḳı iki yüz yigirme törtde Cumāda's s-sān̄ī ayıda mührlik nişān bitildi (belirli geçmiş zaman).

Şimdiki zaman: Yarlıkta eylemin içinde bulunulan zaman diliminde başladığını ve sürdügünü bildiren sürerlilik belirten şimdiki zaman kullanımına rastlanmaktadır: (..) bu

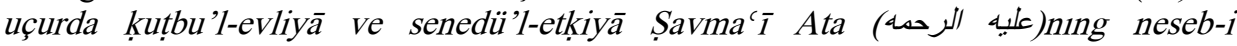
mübārekleri ḥażret-i 'Alī (كرم الله وجها)ga yetişe turur (sürerlilik belirten şimdiki zaman).

Emir (buyurma) kipi: Yarlıkta emir, kuvvetli istek vb. bildiren emir (buyurma) kipine sıklıkla rastlanmaktadır: İmdi bu fermān-1 hümāyun-1 'ālī mażmūnı̀ga mutțali` bolgaç bu mežkūr bolgan camā'atnı tarhān ve marfü'u'l-kalem bilip küllü tekālīf-i dīvān̄ì ve me 'unāt-1 sulțānīdin sivā u müsteșnā bilip küllü 'ameldārlar kademlerin ve ehl-i kalem kalemlerin tarta tutsunlar (buyurma) ve her yerde ékin ékseler ve nihāl tikseler carīb u tanābāne tilemesünler (buyurma) ve yepekleridin māl almasunlar (buyurma), élçi ve yolçı barǵuçı ve kélgüçi öylerige (15) tüşüp kelle ve karalarıdın ulag tutmasunlar (buyurma), bācbān ve keştībān ve korug̉bān ve dervāzebān ve terāzūbān, biy, karavul ve kötevül bir habbe bir dīnār țama' u tavakku' kılmasunlar (buyurma), hīç vechdin żarar u zahmet yétkürüp āzurde-hātı̣ır ḳılmasunlar (buyurma) ve her yılda tāze nişāan tilemesünler (buyurma) tā kim bu mezkūr bolg̀an cemā`at tinç köngül ve āsūde-hātır bolup ba'da ezadā-yı șalavāt-1 hamse bizning du' $\bar{a}-y 1$ devlet-i ebed-muddatımızǵa meşgūul bolgaylar (buyurma).

\subsubsection{Yarlığı Bölümlere Ayıran Belirticiler}

Metni bölümlere ayıran belirticiler anlatının gelişim aşamalarından anlaşılır (Günay 2003: 87). Yarlıktaki bölüm belirticilerine şunlar örnek verilebilir: bes, imdi, tā kim.

(...) selām anıng āl u aṣhāblarıga kim her birini necm-i hādī ḳıldı. Bes makṣūd bu mukaddemedin bu kim hūūrşīd-i ḳadr ve āsmān-1 bedr karıntaşlar birle hukūmet-penāh settāre-sipāh berhūrdār ini ve og̉ullarğa (...) muşārun ileyhimlerining ạ̣vālığa șāmil ḳılıp körüp bilip tarhān ve marfü'u'l-kalem ḳlduk. İmdi bu fermān-1 hümāyun-1 ' $\bar{a} l \overline{1}$ mażmūniga mutțali bolgaç bu mežkūr bolgan camā'atnı (...) her yılda tāze nişān tilemesünler. Tä kim bu mežkūr bolg̀an cemā'at tinç köngül ve āsūde-huātır bolup ba'da

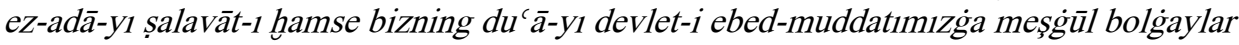
(...) 


\subsection{Yarlığın Tutarlılık Görünümü}

Metnin derin yapısını temsil eden tutarlılık (coherence), metnin anlam ve mantık bakımından uyumunu ifade etmektedir. Bir cümleler topluğunun metin oluşturabilmesi için sadece dilbilgisel düzeyin (bağdaşıklık) uyumluluğu yeterli değildir. Dilbilgisel bakımdan birbiri ile uyumlu olan cümleler konu, anlam ve mantıksal gelişim ve ilişki bakımından da uyumlu değillerse bunlar metin oluşturmuş olmazlar. Kısacası bir metnin metnin olabilmesi için birbiriyle dilbilgisel olarak uyumlu olan cümleler topluluğunun konu, anlam ve mantıksal yapı bakımından da uyumlu (tutarlı) olmaları şarttır. Tutarlılık kavramı bir metindeki cümleler arasında sebep, sonuç, zıtlık, şart, gereklilik, mecaz, kinaye, tariz, eşanlamlılık gibi her türlü anlamsal ilişkinin birbiriyle uyumlu olması demektir (Demirci 2014: 219-220). Bir metni yorumlamak ise varsayımlar yapmak yahut metnin anlamına ilişkin genel çıkarımlarda bulunmak demektir. Bu sonuçlardan da bir yargıya, bir düşünceye ulaşılabilir (Günay 2003: 188).

Daha önce de belirtildiği gibi, metindeki mantıksal bağlantı olarak tanımlanabilen tutarlılık, metinselliği sağlamada yalnızca belirli sözel ögeler etkileşimine dayanmadığından bir metnin tutarlılık yapısını ortaya koyma konusunda yapılan yaklaşımlar farklılık gösterecektir (Subaşı Uzun 1995: 110). Bu çalışmada elimizdeki yarlığın tutarlılık görünümü özelleştirme bağlantısı, sebep-sonuç bağlantısı, amaç bağlantısı, zaman bağlantısı, karşılaştırma bağlantısı gibi açılardan ele alınmıştır.

\subsubsection{Yarlığın Özelleştirme Bağlantısı}

Genel bir göndergenin özelleştirilmesi durumu olan özelleştirme bağlantısı, yarlıkta hem aynı cümle içinde hem de birleşik cümle dizilerinde görülebilmektedir. Yarlıktaki alanı giderek daralan bir özelleştirme bağlantısının yapıldığ 1 görülmektedir:

(...) selām anıng āl u aṣhāblarıga kim her birini necm-i hādī ḳıldı. cümlesinde tüm sahabelerden sonra her biri ile ilgili bir özelleştirme yapılarak; (...) küllü 'ummāl [ve] sekene-i H(W)ārazm husụșan Hīivak (...) cümlesinde ise bütün Harezm'den sonra yönetim merkezi olması hasebiyle en önemli bölgesi olan Hive halkı belirtilerek; (...) küllü 'ameldārlar kademlerin ve ehl-i kalem kalemlerin tarta tutsunlar ve her yerde ékin ékseler ve nihāl tikseler carīb u tanābāne tilemesünler ve yepekleridin māl almasunlar, élçi ve yolçı barğuçı ve kélgüçi öylerige tüşüp kelle ve karalarıdın ulag tutmasunlar, bācbān ve keşt̄̄bān ve ḳoruğbān ve dervāzebān ve terāzūbān, biy, karavul ve kötevül bir habbe bir dīnār tama' u tavakku' kulmasunlar. cümlesinde 'ameldārlar ve ehl-i kalem göndergelerinin bācbān ve keştībān ve korug̉bān ve dervāzebān ve terāzūbān, biy, karavul ve kötevül şeklinde özelleştirilerek göndergeler arasında özelleştirme bağlantısı kurulduğu görülmektedir.

$\mathrm{Bu}$ örneklerde durumla ilgili ayrıntıların aktarılmasında öbeklerdeki dizilerin akışı bozulmadan göndergeler arasındaki özelleştirme bağlantısına dayanılmıştır. Bu özelleştirme bağlantıları metnin bütününde anlatıcının alıcıya aktardığı bilgilerin daha açık biçimde ifade edilmesini sağlamaktadır. 


\subsubsection{Yarlığın Sebep-Sonuç Bağlantısı}

Yarlıkta tutarlılığın sebep-sonuç bağlantısı kullanılarak sağlandığı örneklere de rastlanmaktadir:

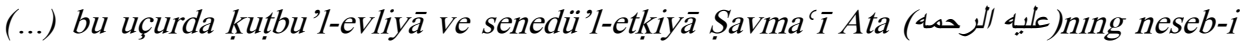
mübārekleri hażret-i 'Alī (كرم الله وجها)ga yetişe turur. Büzürgvār-1 mezkūrning rūhh-1

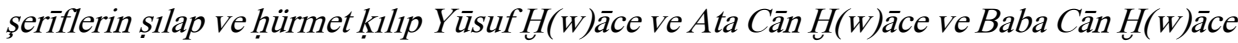
ve Gedāy $H(w) \bar{c} c e$ ve Sikender $H(w) \bar{a} c e$ ve Kalender H(w)āce ve Nūru'd-dīn Mahdūm ve 'Avaż $H(W) a \bar{c} e$ ve Gümān H(W)āce büzürgvār (عليه الرحمد)ning evlādları érkeni hātırir-1 şarîfimıża ma'lūm bolgan üçün žerre-i āftāb-1 'ināyetimizni muşārun ileyhimlerining aḥvālıga şāmil ḳılıp körüp bilip tarhān ve marfü‘ u'l-ḳalem ḳılduḳ.

Yukarıdaki cümle dizisinde hanın Savmai Ata'ya hürmetinin sebebi, onun soyu Hz. Ali'ye dayanan bir evliya olmasıdır. Sözü geçen kişilere tarhanlık verilmesinin sebebi ise onların Savmai Ata'nın çocukları olmalarıdır. Buradaki sebep-sonuç bağlantısı, hanın dinî değerlere saygılı olduğunun bir göstergesi olması açısından değerlidir. Çünkü hanın söz konusu kişilere tarhanlık imtiyazı vermesi, dinî duyguya, düşünceye ve anlayışa dayanmaktadır. $\mathrm{Bu}$ bağlantı ilişkisi, metnin bütününde anlatıcının alıcıya metnin oluşturulduğu toplumda genel kabul görmüş kutsal değerler üzerinden bir gönderme yapması açısından ayrıca dikkate değerdir. Böylece metnin alıcılar tarafından daha güçlü bir biçimde benimsenmesi sağlanmaktadır.

\subsubsection{Yarlığın Amaç Bă̆lantısı}

Amaç bağlantısı, önceki eylemin sonraki eylemi sonuç belirtmeden bir amaç doğrultusunda yönlendirmesidir ${ }^{16}$. Yarlıkta amaç bağlantısı, yarlık verilen kişilerin rahat ve huzur içinde hana ve hanlığın bekasına beş vakit namazlarından sonra dua edebilmeleri amacıyla devlet memurlarının onları kesinlikle rahatsız etmemeleri, onlardan herhangi bir istekte bulunmamaları ve vergi almamaları vb. buyurularak gösterilmiştir:

İmdi bu fermān-1 hümāyun-1 'ālī mażmūniga mutțali' bolgaç bu mežkūr bolgan camā'atnı tarhān ve marfü‘ $u$ 'l-kalem bilip küllü tekālīf-i dīvānī ve me 'unāt-1 sulțānīdin sivā u müstesnā bilip küllü 'ameldārlar kademlerin ve ehl-i kalem kalemlerin tarta tutsunlar ve her yerde ékin ékseler ve nihāl tikseler carīb u țanābāne tilemesünler ve yepekleridin māl almasunlar, élçi ve yolçı barg̉uçı ve kélgüçi öylerige tüşüp kelle ve karalarıdın ulag tutmasunlar, bācbān ve keştībān ve koruġbān ve dervāzebān ve terāzūbān, biy, karavul ve kötevül bir habbe bir dīnār țama‘ u tavakku' ḳlmasunlar, hīç vechdin żarar u zahmet yétkürüp āzurde-hātır kılmasunlar ve her yılda tāze nişān tilemesünler. Tā kim bu mezkūr bolgan cemā'at tinç köngül ve āsūde-h̆âtır bolup ba'da ez-adā-yı șalavāt-1 hamse bizning du' $\bar{a}-y 1$ devlet-i ebed-muddatımızǵa meşg்ūl bolgaylar (...)

\subsubsection{Yarlı̆̆ın Zaman Bă̆lantısı}

Metinlerde zaman bağlantısı zaman belirlemesi yapan bir sözlüksel birim olmaksızın metin alıcısının kuracağı/kurabileceği bir içerik bağlantısı ile kurulabileceği gibi 
doğrudan bir sözlüksel birimle yüzey metin düzleminde işaretlenerek de kurulabilir. Zaman bağlantılarının kurulmasında bağdaşıklık ögelerinden eylemlerdeki zaman ekleri önemli bir işlev üstlenmektedir (Subaşı Uzun, 1995: 126-129).

Hamd ol pād-şāhīga kim țabakāat-1 āsmānnı (و لقد زينا السما و الدنيا بزينة الكواكب) birle müzeyyen

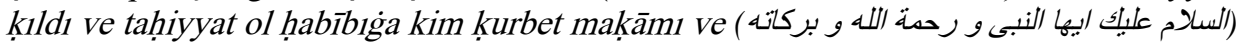

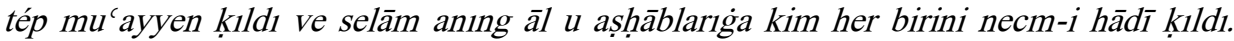
Cümle dizilerinde pād-şăh olarak nitelenen tanrının gökyüzünü yarattıktan sonra hăabīb olarak nitelenen peygambere kurbet makamı verdiğini ve daha sonra peygamberin $\bar{a} l \mathrm{ve}$ așhāblarının her birini necm-i hā $\bar{i}$ kıldığ 1 belirtilmektedir. Cümle dizilerinde belirtilen üç eylem, zamansal olarak ardışık bir yapı sergilemektedir. Buradaki zaman bağlantısı zaman belirleyici bir sözlüksel birim kullanılmadan yapılmıştır.

(...) bu uçurda kuṭbu'l-evliyā ve senedü'l-etkiyā Șavma'ī Ata (علبه الرحمه)ning neseb-i

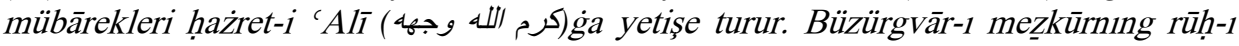
şerîflerin șllap ve hürmet ḳllp Yūsuf Hu(w)āce ve Ata Cān H(W)āce ve Baba Cān H(w)āce ve Gedāy $H(w) a \bar{c} e$ ve Sikender $H(w) a \bar{c} e$ ve Kalender H(w)āce ve Nüru'd-dīn Mahdūm

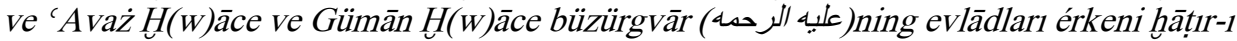
şarīfimıż̀a ma' lūm bolg̀an üçün zerre-i âftāb-1 'ināyetimizni muşārun ileyhimlerining ahvālig̉a şāmil killp körüp bilip tarhān ve marfü' u'l-kalem kıllduk.

Yukarıdaki cümle dizilerinde zaman bağlantısı, dilbilgisel bakımdan sebep edatı olan üçün'ün "-dAn sonra" anlamında zaman bağlantısı olarak kullanılması ile sağlanmıştır. Han burada adı geçen kişilerin Savmai Ata'nın çocukları olduğunu öğrendikten sonra onlara tarhanlık verdiğini ifade etmektedir.

$\mathrm{Bu}$ cümle dizilerinin devamında dilbilgisel olarak cümle başı zaman edatı olan imdi sözlüksel birimi, "bundan sonra" anlamı ile önceki cümle ile sonraki cümleler arasında zaman bağlantısı kurmuştur. Buradaki zaman bağlantısı "-DIĞIndA, -IncA" anlamlarında dilbilgisel olarak zaman ulacı işlevinde olan -gaç morfemiyle pekiştirilmiştir. Bu cümle dizisinde Han, bu yarlı̆̆g gördükten sonra tüm devlet memurlarının adı geçen kişilere tarhanlıktan doğan tüm imtiyazları sağlamalarını buyurmaktadır:

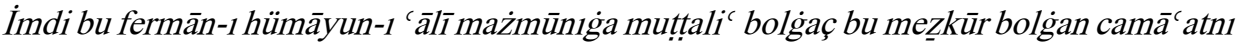
tarhān ve marfü'u'l-kalem bilip küllü tekālīf-i dīvānī ve me'unāt-1 sulțānīdin sivā u müstesnā bilip küllü 'ameldārlar kademlerin ve ehl-i kalem kalemlerin tarta tutsunlar (...)

\subsubsection{Yarlı̆̆ın Karşılaştırma Bă̆lantısı}

Yarlıkta karşımıza çıkan tutarlılık bağlantılarından biri de karşılaştırma bağlantısıdır. Yarlıktaki karşılaştırma bağlantısı, iki ayrı göndergenin birbiriyle karşılaştırılması ile değil aynı göndergenin ögesi ile bütününün karşılaştırılması yoluyla oluşturulmuştur. $\mathrm{Bu}$ bağlantının varlığı sayesinde bazı bilgilerin sezdirim yoluyla metin alıcısına aktarıldığı söylenebilir:

Büzürgvār-1 mezkūurnıng rūhh-1 şerīflerin șllap ve hürrmet ḳ1lp Yūsuf H(w)āce ve Ata Cān $H(W) \bar{a} c e$ ve Baba Cān $H(W) a \bar{c} e$ ve Gedāy $H(w) \bar{a} c e$ ve Sikender $H(W) \bar{a} c e$ ve Kalender

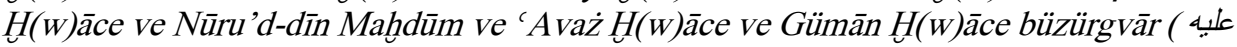

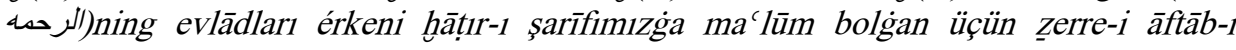


'ināyetimizni muşārun ileyhimlerining aḥvālı̀ga şāmil ḳ1lı körüp bilip tarhāan ve marfü' u'l-kalem kılduk.

Yukarıdaki cümle dizisinde metin üreticisi, zerre-i āftāb-1 'ināyet kelime öbeğinde geçen zerre sözlüksel birimi ile metin alıcısına söz konusu bu tarhanlık imtiyazının -ki çalışmanın giriş bölümünde değinildiği gibi bu imtiyaz oldukça önemlidir.- güneş gibi olan lütfunun ('ināyet) sadece bir zerresini gösterdiğini belirtmektedir. Bu sözlüksel birimden sezdirim yoluyla hanın başkalarına da bu tür ihsanlarda çokça bulunduğu anlaşılmaktadır. Metin alıcısı, bu sonuca metin dışı bilgilerinin de yardımıyla kolayca ulaşabilmektedir. Nitekim Muhammed Rahim Bahadur Han’ın başka tarhanlık yarlıkları olduğu metin dışı bir gerçekliktir.

\section{YARLIĞIN ÇEVIRİ YAZISI}

Bu bölümde çalışmada ele alınan tarhanlık yarlığının çeviri yazısı yapılmıştır. Ele alınan metin, tek sayfadan oluşmaktadır. $O$ yüzden burada metnin sadece satırları numaralandırılmıştır. Metinde geçen Arapça söz veya öbekler parantez içinde ve Arap harfleri ile dizilmiştir.

\section{(1) $H \bar{u}$}

\section{(2) Ebu'l-mużaffer ve'l-manșūr Muhammed Raḥīm Bahādur hān sözümiz}

(3) Hamd ol pād-şāhīga kim țabaḳāt-1 āsmānnı birle

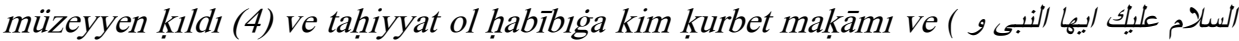

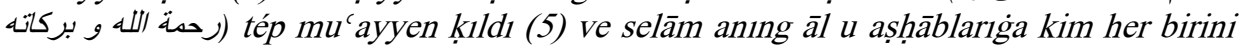
necm-i hādī kıldı. Bes makṣūd bu mukaddemedin bu kim hū̄sşīd-i kadr ve āsmān-ı bedr karıntaşlar birle (6) ḥukūmet-penāh settāre-sipāh berhūrdār ini ve og̉ullarğa, 'ālī-makām sa'ādet-fercām diyānet ve şecā'atlık șāyib-rāy karaçu biy'lilerge, (7) zerrīn-kalem ve

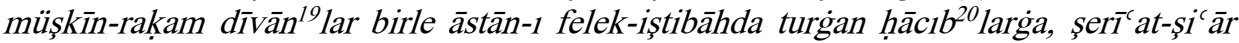

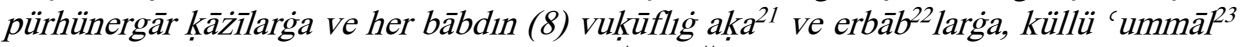
[ve] sekene-i h. h(W)ārazm hușūṣan Hīvak (حسن الله /حوالهم) ga bu uçurda kuṭtbu'l-evliyā ve

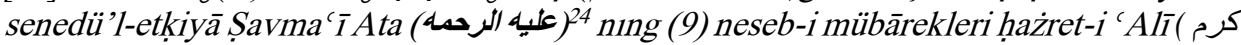
(الله وجهه Yūsuf H(w)āce (10) ve Ata Cān H(w)āce ve Baba Cān H(w)āce ve Gedāy H(w)āce ve Sikender H(w)āce ve Kalender H(W)āce ve Nūru'd-dīn Mahdūm ve 'Avaż $H(w) a \bar{c} c e$ ve Gümān H(W)āce büzürgvār (11) (عليه الرحمد)ning evlādları érkeni hāṭr-1 şarîfimıża ma' lūm bolgan üçün zerre-i āftāb-1 'ināyetimizni mușārun ileyhimlerining aḥvālıga şāmil kılıp (12) körüp bilip tarhān ve marfü'u'l-kalem ḳlduk. Imdi bu fermān-1 hümāyun-1 'ālī

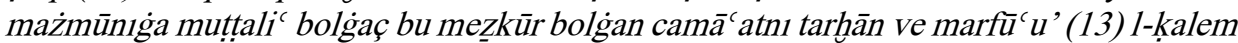
bilip küllü tekālīf-i dīvānī ve me'unāt-1 sultānīdin sivā u müstesnā bilip küllü 'ameldār ${ }^{25}$ lar kademlerin ve ehl-i kalem ${ }^{26}$ kalemlerin tarta tutsunlar (14) ve her yerde ékin ékseler ve nihāl tikseler carī ${ }^{27}$ u tanābāne ${ }^{28}$ tilemesünler ve yepekleridin māp9 almasunlar, élçi ve yolçı barğuçı ve kélgüçi öylerige (15) tüşüp kelle ve karalarıdın ulag ${ }^{30}$ tutmasunlar, bācbān ${ }^{31}$ ve keştībān ${ }^{32}$ ve korug̉bānn ${ }^{33}$ ve dervāzebānn ${ }^{34}$ ve terāzūbānn ${ }^{35}$, biy $y^{36}$,

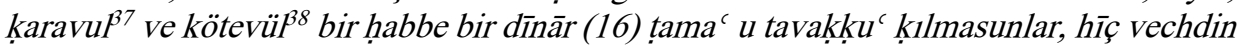
żarar u zaḥmet yétkürüp āzurde-hātır ḳlmasunlar ve her yılda tāze nişān tilemesünler. (17) Tā kim bu mezkūr bolgan cemā' at tinç köngül ve āsūde-hātıtır bolup ba' da ez-adā-yı 


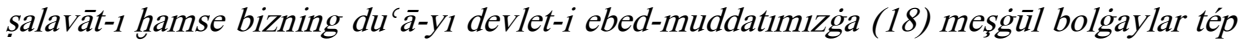
tārīhh-i hicrī ming taḳı iki yüz yigirme törtde cumāda șsșānī ayıda mührlik nişān bitildi. Sene 1224.

\section{SONUÇ}

20. yüzyılın ikinci yarısından itibaren ortaya çıkan ve yüzyılın sonlarına doğru yaygınlaşmaya başlayan metindilbilim çalışmaları, metinlerin geleneksel metodlardan farklı bir biçimde incelenmesi esasına dayanır. Bu çalışmada Hive hanlığının (15111920) son hanlarından Muhammed Rahim Bahadur (1806-1825)'un 1809 tarihli bir yarlığı metindilbilimsel açıdan incelenmiştir. Söz konusu yarlık, 19. yüzyıl Çağatay Türkçesi ile yazılmıştır. Hive hanı Muhammed Rahim Bahadur Han tarafından Savmai Ata adlı bir evliyanın dokuz oğluna tarhanlık verildiğini belirten bir yarlıktır. Yarlık, tarhanlık verilen kişilere askeri, siyasi, ekonomik vb. açıdan birçok ayrıcalık tanındığını bildirmektedir.

Çalışmada elimizdeki yarlığın üslubu ve metindilbilimsel bakımdan bağdaşıklık görünümü üzerinde durulmuştur. Üslup bakımından yapılan incelemede yarlıkta intitulatio (elkap), arrenga (giriş/dua/niyaz/invocatio), promulgatio (bilgilendirme/duyuru), dispositio (talep), narratio (nakil/anlatım), sanctio (tasdik), corroboratio (teyit), datatio (tarih) bölümlerinin bulunduğu; başka yarlıklarda görülebilen locus (yer) bölümünün ise eksik olduğu görülmektedir.

Bağdaşıklık görünümü bakımından ise yarlık yinelenmeye dayalı yapısı, art gönderimsel yapısı, bağlantı ögeleri, örtüklük yapısı, eksiltili yapısı, izleksel (tematik) yapısı, dilbilgisel eylem zamanları ve yarlığı bölümlere ayıran belirticiler gibi çeşitli açılardan incelenmiştir. Buna göre yarlıkta bu mežkūr bolgan camā'at ile tarhān ve marfü'u' lkalem öbeklerinin iki kez yinelendiği görülmektedir. Yarlıkta önce adı söylenen Savma'` Ata'dan daha sonra büzürgvār-1 mezkūrnıng ve büzürgvār şeklinde söz edilerek art gönderim yapılmıştır. Benzer şekilde önce Savmai Ata'nın oğullarının adı zikredilmiş, akabinde aynı kişilere muşārun ileyhim ve bu mežkūr bolg̀an camā' at göndergesiyle yeni bir art gönderim daha yapılmıştır. Yarlıkta en çok kim, ve, $u$, birle bağlantı ögeleri kullanılmıştır. Diğer bağlantı ögeleri ise şunladır: bes, imdi, tā kim, tép. Yarlığın Türkİslam toplumlarında görülen kültür çevresinde üretilmiş olması, alıcının da benzer şekilde aynı çevreye ait olması nedeniyle yarlıkta Türk-İslam kültürüne ait kültürel örtüklüğü ifade eden durumlara rastlanmaktadır. Örneğin yarlık, "Allah" anlamına gelen "hü" kelimesi ile başlar. Yarlıkta (Mén) Ebu'l-mużaffer (bolġan) ve'l-manșūr (bolg̀an) Muhammed Raḥīm Bahādur ḩān (mén). (Bizning) sözümiz (bu durur kim) gibi özne, yüklem, tümleç, fiilimsi, iyelik eki vb. eksiltili yapıların kullanılmış olduğu görülmektedir. Ancak bu eksiltili yapılar metnin anlaşılmasını zorlaştırmamakta, tam aksine metnin anlaşılırlığına ve akıcılığına katkıda bulunmaktadır. Elimizdeki yarlı̆̆ın temel izleği ise Savmai Ata'nın oğullarına tarhanlık verilmesidir. Ancak yarlıkta temel izleğin örgesi (motif) iken örgeleri olan alt izlek durumuna geçen örgelere de rastlanmaktadır. Yarlıkta geçen dilbilgisel eylem zamanları geçmiş zaman, şimdiki zaman ve gelecek zamandır. Bir ferman olmasının doğal sonucu olarak yarlıkta emir (buyurma) kipi de sıklıkla kullanılmıştır. Yarlıktaki bölüm belirticilerine ise şunlar örnek verilebilir: bes, imdi, tā kim. 
Yarlığın tutarlılık görünümü ise özelleştirme bağlantısı, sebep-sonuç bağlantısı, amaç bağlantısı, zaman bağlantısı, karşılaştırma bağlantısı gibi açılardan ele alınmıştır. Buna göre yarlıkta tüm sahabelerden sonra her biri ile ilgili bir özelleştirme yapılarak; bütün Harezm'den sonra yönetim merkezi olması hasebiyle en önemli bölgesi olan Hive halk1 belirtilerek; 'ameldārlar ve ehl-i kalem göndergelerinin bācbān ve keştībān ve koruğbān ve dervāzebān ve terāzūbān, biy, karavul ve kötevül şeklinde özelleştirilerek göndergeler arasında özelleştirme bağlantısı kurulduğu görülmektedir. Han'ın Savmai Ata'ya hürmetinin sebebi, onun soyu Hz. Ali’ye dayanan bir evliya olmasıdır. Sözü geçen kişilere tarhanlık verilmesinin sebebi ise onların Savmai Ata'nın çocukları olmalarıdır. Buradaki sebep-sonuç bağlantısı, hanın dinî değerlere saygılı olduğunun bir göstergesi olması açısından değerlidir. Yarlıkta amaç bağlantısı, yarlık verilen kişilerin rahat ve huzur içinde hana ve hanlığın bekasına beş vakit namazlarından sonra dua edebilmeleri amaciyla devlet memurlarının onları kesinlikle rahatsız etmemeleri, onlardan herhangi bir istekte bulunmamaları ve vergi almamaları vb. buyurularak gösterilmiştir. Tanrının gökyüzünü yarattıktan sonra habīb olarak nitelenen peygambere kurbet makamı verdiğini ve daha sonra peygamberin $\bar{a} l$ ve așhāblarının her birini necm-i hādī kıldığı belirtilmektedir. Cümle dizilerinde belirtilen üç eylem, zamansal olarak ardışık bir yapı sergilemektedir. Buradaki zaman bağlantısı zaman belirleyici bir sözlüksel birim kullanılmadan yapılmıştır. Yarlıktaki karşılaştırma bağlantısı, iki ayrı göndergenin birbiriyle karşılaştırılması ile değil aynı göndergenin ögesi ile bütününün karşılaştırılması yoluyla oluşturulmuştur: žerre-i $\bar{a} f t a \bar{b}-1$ 'ināyet.

Yarlık 18 satırdan oluşmaktadır. Yarlığın Hicrî 1224 senesinin Cumada's-sani ayında yazıldığ 1 belirtilmiştir. Bu tarih, Miladî 1809 yılının Temmuz veya Ağustos aylarına tekabül etmektedir.

Elimizdeki yarlığın baş kısmında bulunan övgü ifadeleri dışında sade yazılmış bir metin olduğu söylenebilir. Ayrıca metinde izleğe uygun olarak vergi ve devlet yönetimi ile ilgili birçok terimin geçtiği görülmektedir. 


\section{NOTLAR}

${ }^{1}$ Hive Hanlığ tarihi ile ilgili bilgi için bk. Saray 1994; Saray 1998: 167-170; Saray 1993.

${ }^{2}$ Yuri Bregel, Documents from the khanate of Khiva (17th-19th centuries), Indiana University Denis Sinor Institute for Inner Asian Studies, Bloomington, Indiana, 2007.

${ }^{3}$ Muhammed Rahim Bahadur Han kendisinden önce Hive hanı olan El Tüzer Han'ın kardeşidir. El Tüzer'in öldürülmesi üzerine 1806 yılında hanlık tahtına oturmuştur. Muhammed Rahim Bahadur Han'ın hayatı hakkında en önemli kaynak Munis Harezmi (1778-1829) tarafindan başlanan ve yeğeni Muhammed Riza Mirab Agehi (1809-1874) tarafindan tamamlanan Firdevsü'l-İkbal adlı tarih kitabıdır. Firdevsü'l-İkbal'de Muhammed Rahim Han döneminin ilk yedi yılını Munis Harezmi yazmış, ölümü üzerine 1813-1825 yılları arasındaki dönem ise yeğeni Agehi tarafından tamamlanmıştır. Muhammed Rahim Bahadur'un anlatıldığı bölümler Firdevsü'l-İkbaP in beşinci babının ikinci yarısında yer almaktadır. Daha fazla bilgi için bk. Bregel 1999; Kaman 2012; Şişman 2012.

${ }^{4}$ Bregel, bu tarihi 1810 olarak çevirmiştir.

${ }^{5}$ Bregel 2007:19-20.

${ }^{6}$ Tarhanlık, eski Türklerde yüksek rütbeli devlet görevlilerine verilen bir unvanı; Türk ve Moğol devletlerinde hükümdar tarafından bazı devlet adamlarına tanınan geniş imtiyazı ifade eden terimsel bir kelimedir. Eski Türk hukuk terimlerinden biri olan tarhanlık, Türklerde ve Moğollarda çeşitli anlam ve temsil gücüne sahip olmakla birlikte genel olarak devlete hizmeti geçen veya hükümdarın teveccühünü kazanmış kimselere hükümdar tarafindan askerî, ticarî ve hukukî açıdan birçok imtiyazlık ile bütün vergilerden muaf tutulma hakkı verilmesi anlamına gelmektedir (Özyetgin 1996: 75-77; Ahmetbeyoğlu 2011: 19-20).

7 Yarlık, Büyük Türkçe Sözlük'e göre "ferman" anlamında bir tarih bilimi terimidir. Yarlık kelimesi, yarlıka- şeklinde türemiş fiil olarak "(Tanrı) buyurmak, lutfetmek, esirgemek" anlamında Orhun Yazıtlarında; yarlıg şeklinde Eski Uygur metinlerinde, Divanu Lugati'tTürk'te, Karahanlı, Harezm, Çağatay ve Osmanlı Türkçesi sahalarında "emir, ferman" anlamında teknik bir terim olarak geçmektedir. Yarlık hakkında daha fazla bilgi ve kelimenin etimolojisi ile ilgili tartışmalar hakkında bk. Özyetgin 1996: 73-74; Kamalov 2013: 334-335.

${ }^{8}$ Hayatı hakkında herhangi bir bilgiye sahip olmadığımız Savmai Ata'nın soyunun direkt olarak Hz. Ali'ye bağlanmasından, başka bir deyişle arada herhangi bir silsile gösterilmemiş olmasından dolayı Bregel'in bu bilgiye temkinli yaklaştığı anlaşılmaktadır: Sawma'‘̄ Ata (whose lineage is also mentioned in doc. No. 7 as Sawma' a Atayi who traced themselves back to calif 'Alī) seems to be otherwise not known (Bregel 2007: 69). Bizce de bu düşünce mantıklıdır.

${ }^{9}$ Bregel, burada bizim unutulmuş olduğunu varsaydığımız [ve] bağlacının göz önüne almadığından İngilizce özet çevirisinde burada bahsedilen "Harezm, özellikle Hive halkı"ndan söz etmemektedir. O, burayı Harezm'deki, özellikle Hive'deki tüm memurlar olarak anlamıştır.

${ }^{10}$ Metinde hana verilmiş herhangi bir dilekçeden açıkça söz edilmemekle beraber Bregel, sözü geçen oğulların Han'a bir dilekçe verdikleri kanaatindedir (Bregel 2007: 20). Biz de bu düşünceye katılmaktayız.

${ }^{11}$ Metindilbilim üzerinde son yıllarda Türkiye'de yeni çalışmalar yapılmıştır. Örnek olarak bk. Subaşı Uzun 1995, Günay 2003, Ayata Şenöz 2005, Aktulum 1999, Aktulum 2004, Aşkın Balcı 2006, Aşkın Balc1 2009, Özkan 2004, Öztokat 2005, Parlak 2009, Günay 2013, Dilidüzgün, 2017. 
${ }^{12}$ Metindilbilimsel incelemelerin en temel iki ölçütü bağdaşıklık ve tutarlılık olmakla birlikte bazı araştırmacılar bu ölçütlere amaçlllık, kabul edilebilirlik, durumsallık, bilgi vericilik ve metinlerarasılık (bk. Toklu 2003: 124-132) gibi ölçütler de eklemektedirler.

13 Bregel, yazmadaki ķarıntaşlar kelimesini akrabalar "relatives" şeklinde çevirmiştir (Bregel 2007: 19) ki bizce de bu bağlamsal açıdan doğru bir yaklaşımdır.

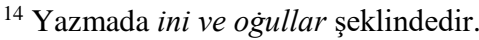

15 Daha önce belirtildiği üzere, Bregel'e göre bu kişiler Han'a dilekçe yoluyla başvurmuşlardır (Bregel 1995: 20). Bu durumda buraya “Savmai Ata'nın Han'a dilekçe sunmaları"nı da bir örge olarak düşünmek mümkündür. Ancak bu örge, metinde çok açık bir şekilde ifade edilmemektedir.

${ }^{16}$ Bu bağlantı ilişkisini Subaşı Uzun, Neden Bağlantısı olarak ifadelendirmiştir (Subaşı Uzun 1995: 124-125).

${ }^{17}$ Kur'an-1 Kerim 37: 6.

${ }^{18}$ Devlet yönetiminde önemli bir yönetici. Daha fazla bilgi için bk. Bregel 2007: 65-66.

${ }^{19}$ Çeşitli rütbelerde sivil memurlar için kullanılan bir terim. Daha fazla bilgi için bk. Bregel 2007: 63.

20 Teşrifatç1. Daha fazla bilgi için bk. Bregel 2007: 63.

${ }^{21}$ Şehirlerde Sart devlet memurlarına verilen bir unvan. Aḳa, arbâb'dan bir derece daha yüksektir. Daha fazla bilgi için bk. Bregel 2007: 61.

${ }^{22}$ Şehirlerde Sart devlet memurlarına verilen bir unvan. Daha fazla bilgi için bk. Bregel 2007: 61.

23 Tahsildarlar.

${ }^{24}$ Daha önce de belirtildiği üzere, tıpkıbasımda bu bölümün mürekkepleri dağılmıştır. Ancak Bregel, yazmanın sağ üst köşesinde yazılı bulunan "Șavma'ī Ata (عليه الرحمه)"nın burada yer aldığını belirtmektedir (Bregel 2007: 19).

${ }^{25}$ Tüm devlet memurları için kullanılan bir unvan. Daha fazla bilgi için bk. Bregel 2007: 61 .

${ }^{26}$ Tüm sivil devlet memurları, özellikle kâtipler için kullanılan bir unvan. Daha fazla bilgi için bk. Bregel 2007: 61.

${ }^{27}$ Bir ölçü birimi iken yarlıkta bir tür vergilendirme terimi kullanılmaktadır. Daha fazla bilgi için bk. Bregel 2007: 64.

${ }^{28}$ Yarlıkta bir tür vergi terimi anlamındadır. Daha fazla bilgi için bk. Bregel 2007: 68.

${ }^{29}$ Bir tür genel vergi terimi iken yarlıkta sadece ipeklerden alınan vergi anlamındadır. Daha fazla bilgi için bk. Bregel 2007: 65.

${ }^{30}$ Hanın elçi ve habercilere hayvan sağlama vergisi. Daha fazla bilgi için bk. Bregel 2007: 68 .

${ }^{31}$ Gümrük memuru. Daha fazla bilgi için bk. Bregel 2007: 61.

${ }^{32}$ Amu Derya'daki gemi kaptanı. Daha fazla bilgi için bk. Bregel 2007: 64.

${ }^{33}$ Han'a ait koruların koruyucusu olan devlet memuru. Daha fazla bilgi için bk. Bregel 2007: 66.

${ }^{34}$ Şehirlerdeki kale kapısını koruyan ve vergi alan devlet memuru. Daha fazla bilgi için bk. Bregel 2007: 63.

${ }^{35}$ Pazarlardaki mallardan vergi toplayan devlet memuru. Daha fazla bilgi için bk. Bregel 2007: 68 .

${ }^{36}$ Komutan, bey. Daha fazla bilgi için bk. Bregel 2007: 61-62.

${ }^{37}$ Karakol. Daha fazla bilgi için bk. Bregel 2007: 66.

${ }^{38}$ Bir çeşit devlet memuru. Daha fazla bilgi için bk. Bregel 2007: 64-65. 
EK 1. Yarlığın Tıpkıbasımı

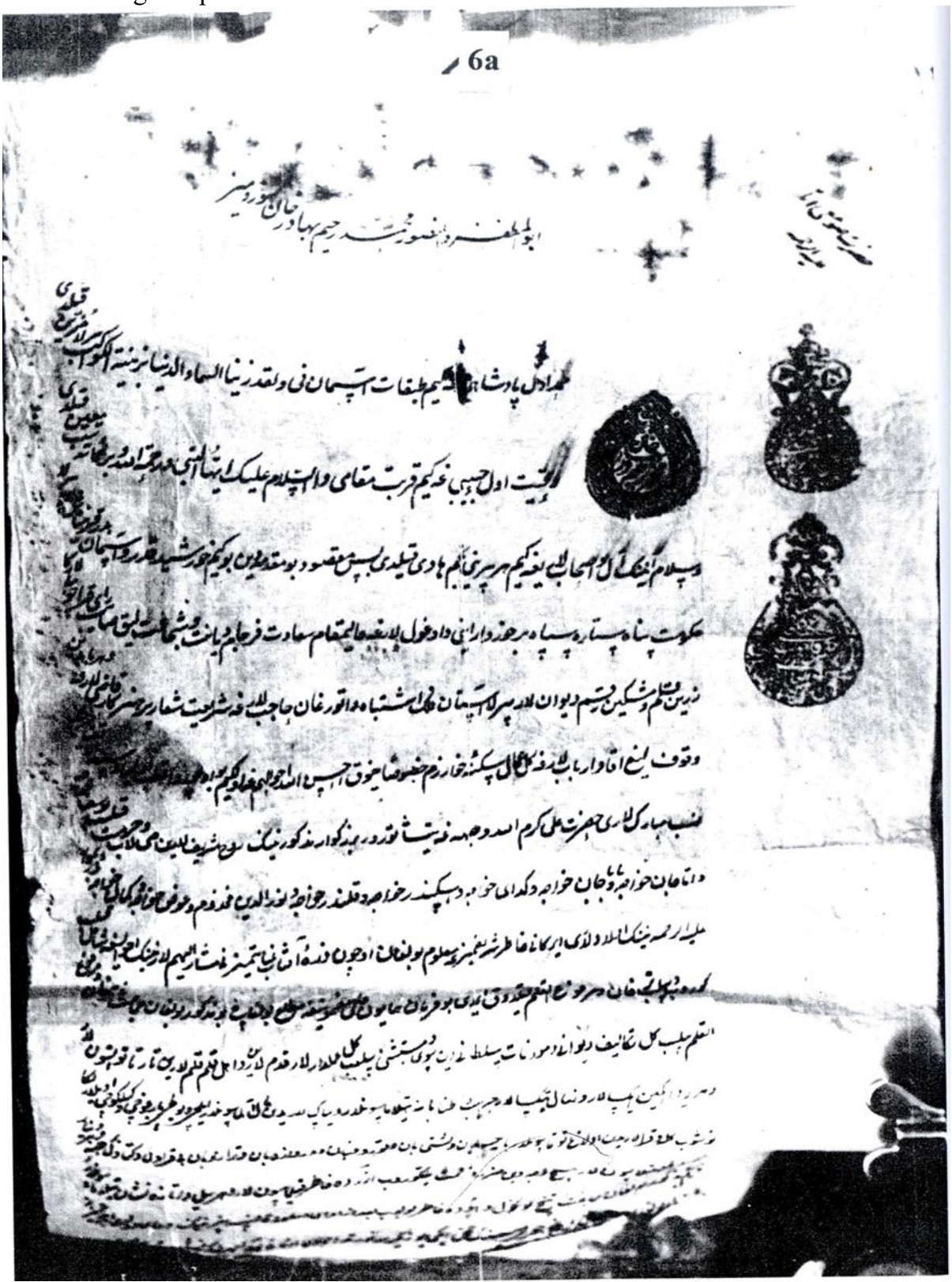

Kaynak: Bregel (2007) 


\section{KAYNAKÇA}

Ahmetbeyoğlu, A. (2011). “Tarhan”, TDVİA. 40: 19-20. İstanbul. (Erişim: 16.12.2013), http://www.islamansiklopedisi.info

Akbayır, S. (2013). Cümle ve Metin Bilgisi (Eğitim Fakülteleri Için). Ankara: Pegem Akademi Yayınları.

Aktulum, K. (1999). Metinlerarası İlişkiler. Ankara: Öteki Yayınları.

Aktulum, K. (2004). Parçalılık Metinlerarasılık. Ankara: Öteki Yayınları.

Alpargu, M. (2002). “Türkistan Hanlıkları”, Türkler Ansiklopedisi. 557-605.

Aşkın Balcı, H. (2006). Metindilbilim Açısından Bir Çözümleme. Erciyes Üniversitesi Sosyal Bilimler Enstitüsü Dergisi, 21, 191-204.

Aşkın Balcı, H. (2009). Metindilbilime Kavramsal Açıdan Genel Bir Bakış. Ankara: 24 Saat Yayıncilik.

Ayata Şenöz, C. (2005). Metindilbilim ve Türkçe. İstanbul: Multilingual.

Aydın, İ., \& Torusdağ, G. (2014). Türkçe Öğretimi Çerçevesinde Yazınsal Bir Metin Çözümleme Örneği Olarak Refik Halit Karay’ın Garip Bir Hediye'si. Uluslararası Türkçe Edebiyat Kültür Eğitim Dergisi, (3/4), 109-134.

Bregel, Y. (1999). Shir Muhammad Mirab Munis and Muhammad Riza Mirab Agahi, Firdaws al-iqbāl (History of Khorezm). Köln: Brill.

Bregel, Y. (2007). Documents from the khanate of Khiva (17th-19th centuries). Bloomington, Indiana: Indiana University Denis Sinor Institute for Inner Asian Studies.

Demirci, K. (2014). Türkoloji Iç̧in Dilbilim Konular Kavramlar Teoriler. Ankara: Anı Yayıncilik.

Dilidüzgün, Ş. (2017). Metindilbilim ve Türkçe Öğretimi - Uygulamalı Bir Yaklaşım. Ankara: Anı Yayıncılık.

Günay, D. (2003). Metin Bilgisi. İstanbul: Multilingual.

Günay, D. (2013). Söylem Çözümlemesi. İstanbul: Papatya Bilim.

Kamalov, İ. (2013). "Yarlık”. TDVIA, 43: 334-335. İstanbul. (Erişim: 16.12.2013), http://www.islamansiklopedisi.info

Kaman, S. (2012). Firdevsü'l-İkbal: Giriş-transkripsiyonlu metin (Vr.156b-336a)inceleme-dizin. Doktora Tezi. İstanbul: Marmara Üniversitesi.

Karaağaç, G. (2015). Dil Bilgisi ve Anlam Bilgisi Çözümlemeleri. Ankara: Akçağ Yayınlar1.

Karasoy, Y. (1998). Şiban Han Dîvânı (İnceleme-Metin-Dizin-Tıpkıbasım), Ankara: TDK. 
Onursal, İ. (2003). Türkçe Metinlerde Bağdaşıklık ve Tutarlılık. (hz. Ayşe Kıran, Ece Korkut, Suna Ağıldere), Günümüz Dilbilim Çalışmaları (s.121-132). İstanbul: Multilingual Yayınları.

Özkan, B. (2004). Metindilbilimi, Metindilbilmsel Bağdaşıklık ve Haldun Taner'in 'On İkiye Bir Var’ Öyküsünde Metindilbilimsel Bağdaşıklık Görünümleri. Çukurova Üniversitesi Sosyal Bilimler Enstitüsü Dergisi. 13(1), 167-182.

Öztokat, N. (2005). Yazınsal Metin Çözümlemesinde Kuramsal Yaklaşımlar. İstanbul: Multilingual Yayınları.

Özyetgin, A. M. (1996). Altın Ordu, Kırım ve Kazan Sahasına Ait Yarlık ve Bitiklerin Dil ve Üslûp Incelemesi. Ankara: TDK.

Parlak, H. (2009). Kutadgu Bilig'in Metindilbilimsel Yapısı. Doktora Tezi. Ankara: Gazi Üniversitesi.

Saray, M. (1993). Özbek Türkleri Tarihi. İstanbul: Nesil Yayınları.

Saray, M. (1994). Rus İşgali Devrinde Osmanlı Devleti ile Türkistan Hanlıkları Arasındaki Siyasi Münasebetler (1775-1875). Ankara: TTK.

Saray, M. (1998). “Hive Hanlığı”. TDVİA, 18: 167-170. İstanbul. (Erişim: 16.12.2013), http://www.islamansiklopedisi.info

Subaşı Uzun, L. (1995). Orhun Yazıtlarının Metindilbilimsel Yapısı. Ankara: Simurg Yayınları.

Şeyh Süleyman Efendi-i Buhârî (1298). Lugat-i Çağatay ve Türkî-i Osmânî. İstanbul.

Şişman, R. Ş. (2012). Firdevsüll-Ikkbal, giriş-transkripsiyonlu metin: Vr. 336a-523a. Doktora Tezi. İstanbul: Marmara Üniversitesi

TDK (2016). Büyük Türkçe Sözlük. (Erişim: 16.12.2016), http://tdk.gov.tr/index .php?option=com_bts\&view=bts

Toklu, O. (2003). Dilbilime Giriş. Ankara: Akçă̆ Yayınları. 